\title{
THE IMPLICATIONS OF THE UKRAINE CRISIS FOR NATO'S SOLIDARITY: NATO BETWEEN COOPERATIVE SECURITY AND COLLECTIVE DEFENCE
}

Arif BA $\breve{G B A S S L I O G ̆ L U}$

Citation/(O): Bağbaşlıoğlu, Arif (2016). The Implications of the Ukraine Crisis For NATO's Solidarity Cooparative Security and Collective Defence, Hitit University Journal of Social Sciences Institute, Year 9, Issue 2, December 2016, pp. 651-664

Abstract: This study aims to evaluate the implications of the Ukraine crisis about NATO, which is fundamentally a defensive alliance. This article discusses the Ukraine crisis as a problem in which NATO's deterrence function, which is vital for NATO to persist as a strong alliance, has been tested in the context of its relations with the Russian Federation.The tension following the Ukraine crisis may affect the ranking of priorities among NATO's fundamental tasks, which may also disrupt cooperative security, one of NATO's three essential core tasks. This article analyzes the Ukraine crisis and the violation of NATO's member states' air spaces within the scope of Russia's military presence in Syria as examples, which NATO's solidarity and its deterrence capability have been tested. It evaluates NATO's attitude about these issues to claim that Russia, which had sanctions imposed on it by NATO and the EU after the Ukrainian crisis, aims to transform the different attitudes towards Russia among NATO's European members into a political fracture. Whether this aim will be fulfilled or not depends on the level of solidarity among NATO countries.

Keywords: NATO's solidarity, Ukraine Crisis, Deterrence, Turkey, Russia.

Makale Geliş Tarihi: 01. 08. 2016/ Makale Kabul Tarihi: 28.11.2016

1 Yrd. Doç. Dr. Ahi Evran Üniversitesi, İ̈BF, Uluslararası İlişkiler Bölümü, e-posta: abagbaslioglu@yahoo.com. 


\section{Ukrayna Krizinin NATO'nun Dayanışmasına Etkileri: İşbirliğine Dayalı Güvenlik İle Kolektif Savunma Arasında NATO}

Atıf/O: Bağbaşlıoğlu, Arif (2016). Ukrayna Krizinin NATO'nun Dayanışmasına Etkileri: İşbirliğine Dayalı Güvenlik ile Kolektif Savunma Arasında NATO, Hitit Üniversitesi Sosyal Bilimler Enstitüsü Dergisi, Yıl 9, Sayı 2, Aralık 2016, ss. 651-664

Özet: Bu çalışma, Ukrayna'daki krizin, özünde bir savunma ittifakı olan NATO'ya yansımalarını konu almaktadır. Çalışmada, Ukrayna krizi, NATO’nun güçlü bir ittifak olarak devamı açısından hayati önem taşıyan caydirıcılı fonksiyonunun, Rusya ile olan ilişkiler bağlamında test edildiği bir sorun olarak ele alınmıştır. Ukrayna krizi sonrasinda yaşanan gerilim NATO'nun temel görevleri arasında bir öncelik sıralamasını etkileyebilir ki bu durumda NATO'nun üç temel görevinden biri olan işbirliğine dayalı güvenliği geliştirme amact zarar görebilir. Makale Ukrayna krizini ve Rusya'nın Suriye'deki askeri varlı̆̆ çerçevesinde İttifak üyelerinin hava sahalarını ihlal etmesini NATO dayanışması ve caydınıcıliğının test edildiği örnekler olarak seçerek NATO'nun bu konulardaki tutumunu değerlendirmektedir. Bu çalışmanın temel iddiası, Ukrayna krizi sonrasında NATO ve AB'nin yaptırımlarına maruz kalan Rusya'nın, NATO'nun Avrupalı ülkeleri arasındaki kendisine karşı takınılacak tutum konusundaki farklılıklar İttifak içerisinde siyasi bir çatlağa dönüştürmeyi hedeflemesidir. Bu hedefin gerçekleşip gerçekleşmemesini NATO ülkeleri arasındaki dayanışma düzeyi belirleyecektir.

Anahtar Kelimeler: NATO Dayanışması, Ukrayna Krizi, Caydırıcllı, Türkiye, Rusya.

\section{INTRODUCTION}

In studies on alliances, it is neither easy to reach a description commonly agreed upon for, nor find a consensus on the reasons why countries seek alliances. However, it is generally agreed that the concept of alliance results from a common will to cooperate, especially over security. In this sense, the perception of common interests and common threats among countries forming an alliance is the main element in the concept of alliance. Stephen M. Walt (1987: 5) argues that the main reason for states to form alliances is their wish to counter threats rather than increase their power. Although alterations in the distribution of power also have great importance, Walt claims that geographical proximity, offensive capability and the predicted aggressive intentions of other states are significant factors in constructing a state's threat perception. In the Cold War era, the most notable example fitting to this argument is the formation of the Europe-Atlantic Alliance. The 
most institutionalized product of this alliance is NATO. Although the EuropeAtlantic Alliance and NATO still exist, differences of opinions between the U.S. and European members on many issues, such as security, international law, environment, terrorism, and human rights, have become more apparent in the post-Cold War era.

After the Soviet threat disappeared, NATO has made a noticeable adaptation to the changing security environment. In the post-Cold War era, crisis management, which involves expanding NATO's combat and intervention zone, and cooperative security, which is based on the development of relations with non-NATO member countries, were included in NATO's strategic concepts, and declared in 1991, 1999 and 2010, respectively. In addition, NATO defined collective defence as the alliance's main aim of establishment. With every new strategic concept, salient threats against the alliance were increased. These new strategic concepts draw attention to the variety of threats against NATO's current security. For example, the 2010 Strategic Concept lists current threats as including the proliferation of nuclear weapons and ballistic missiles, instability or conflict beyond NATO borders, cyber-attacks, terrorism, and key environmental and resource constraints. ${ }^{2}$

Member countries differ in how their perceptions of and willingness to balance these threats. Although this has not led NATO to disband, it has caused especially the European Allies to be less eager than the U.S. to participate in and share the costs of NATO's new global tasks. Since 2009, for example, the U.S., highlighting its interests in the Asia-Pacific, a region where officially NATO has little role to play, has developed new regional policies. This has increased the familiar pressure on European countries to allocate more funds for bearing the costs of NATO. NATO's retreat from combat in Afghanistan, the most comprehensive campaign in t's history, has started debates on the future of the Alliance's operational capability. In this context, Russia's aggression during the Ukraine crisis sparked further debates on NATO's reemphasis on its core purpose of territorial defence, or collective defence. ${ }^{3}$ As Kamp (2014: 361) noted, in such an international conjuncture, the Alliance faces the challenge of coping with the legitimate security concerns of NATO's

2 In the document, problems such as the development of laser weapons, electronic warfare and technologies, risks against health, climate change, water scarcity and increasing energy needs have been evaluated as factors that can affect NATO members' security policies. For more information, see, (North Atlantic Council (NAC), 2010).

3 For more information about these debates, see, (Webber, Hallams and Smith, 2014: 773-779; Brown, 2014: 201-209). 
Eastern members, especially Baltic countries, while not simultaneously falling into the trap of creating a one-dimensional "East-Alliance". Many experts and academics warn that the world is facing a new cold war or even a real war between NATO and Russia (Kroenig, 2015: 49-70). According to Walt (2014), who defines NATO's persistence after the Cold War as "something of an anomaly", the Ukraine crisis is significant because it has provided an opportunity for the aging alliance to act together.

This article traces the implications of the Ukraine crisis about NATO, given that it is fundamentally a defensive alliance. The crisis has also clearly affected NATO's unstable relationship with the Russian Federation, while also disturbed the relations and solidarity among NATO member countries. These disturbances, specific to the Ukraine crisis, reflect differences in the interests of NATO countries, which have subsequently appeared as differences in attitudes. These are the dominant determining factors behind the actions of various members. In particular, not all NATO countries perceive the same level of threat from Russia, with Poland and the Baltic states, which share common borders with Russia, being more concerned than other member countries.

The Alliance's connection to the Russian Near Abroad has been established with operations carried out within the framework of NATO's mission of crisis management, NATO's official enlargement and partnership policies since the Cold War ended. (Bağbaşlioğlu, 2015: 2). Considering the completion of the mission of the International Security Assistance Force (ISAF) and the end of NATO's combat mission in Afghanistan in December 2014, it is obvious that the two other policies (enlargement and partnership policies) will attempt to define the NATO's position in the Russian Near Abroad. This study argues that the Ukraine crisis may have a limiting effect on these two basic NATO policies in the Russian Near Abroad.

This study analyzes the Ukraine crisis and the violation of NATO's member states' air spaces within the scope of Russia's military presence in Syria as two examples, which NATO's solidarity and its deterrence capability have been tested. Having evaluated NATO's attitude in these cases, I argue in this article that Russia, upon which NATO and the EU imposed sanctions after the Ukraine crisis, aiming to transform the different attitudes towards Russia among NATO's European members into a political fracture. I briefly discuss the reasons for Russia's coercive and aggressive behaviour, which has transformed the Ukraine crisis into an international issue and damaged the relationship between NATO and the Russian Federation. Then I analyze in what ways the crisis has affected the relationships within the Alliance.

654 | Hitit Üniversitesi Sosyal Bilimler Enstitüsü Dergisi - Yıl 9, Sayı 2, Aralk 2016 


\section{THE UKRAINE CRISIS BECOMING AN INTERNATIONAL ISSUE}

Following the former Ukrainian President Yanukovych's refusal to sign the Ukraine-European Union Association Agreement to enhance the political and economic ties symbolizing Ukraine's move away from Russian influence, anti-government protests broke out in Kiev on 23 November 2013, starting a political crisis in the country. The demands of the Western Ukrainians who participated in the protests and wanted to see their country join Euro-Atlantic institutions led to Yanukovych's overthrow in February 2014. Yanukovych had worked to link the country's foreign policy to the Russian axis. The crisis then spiralled into a military conflict, gradually spreading to the Autonomous Republic of Crimea and the Eastern Ukraine. After President Viktor Yanukovych was ousted, Russia deployed tens of thousands of troops Ukraine's eastern border. Russia's moves encouraged Crimean separatists who finally managed to seize power and stage a referendum. The Supreme Council of Crimea and Sevastopol City Council adopted a declaration of independence on 11 March 2014. On March 18, the treaty to adjoin the Crimean Republic and the city of Sevastopol with the Russian Federation was signed. This development led to demands for annexation by Russia and demonstrations in the Donetsk and Luhansk regions in Eastern Ukraine where the Orthodox population is largely concentrated, and which are also the country's industrial and commercial areas. Considering the importance of Eastern Ukraine to the Ukrainian economy for arms production, nanotechnology and trade, it is clear why the Ukrainian government responded more strongly in this area than in Crimea. ${ }^{4}$

The Russian Federation's first territorial expansion since its establishment caused a reaction in the international community. On March 24, Russia's participation in the G8 meeting was suspended (Borger and Watt, 2014). On March 27, the United Nations General Assembly adopted a resolution declaring that the Crimean referendum had no validity, based on a vote of 100 states in favour and 11 states against, with 58 abstentions including China, India and the great majority of South American countries (UN General Assembly, 2014). Beside this vote, Russian Federation Vice President Dmitry Rogozin's provocative statements, such as that the "Annexation of Crimea by Russia is the end of the unipolar world order" (KyivPost, 2014), and NATO Deputy Secretary General Alexander Vershbow's declaration that "we have to begin to view Russia no longer as a partner but as more of an adversary than a partner" (CBSNEWS 2014), sparked debates about a new Cold War.

4 For more information about Ukrainian government's efforts in Eastern Ukraine, see (Morelli, 2016: 14-20). 
It is the importance of Ukraine for Russian foreign policy that lies behind the Russian attitude that has transformed the crisis in Ukraine into an international issue. Given its geopolitical position in Russia's near abroad, Ukraine is considered a critical country for Russia. In an interview in April 2014, Putin clearly stated that Russia had supported Crimea, not only for the residents of the region but also to prevent NATO's expansion (Herszenborn, 2014). Having the longest eastern border with Russia, Ukraine's key position in the region, extending from the Baltic to the Caspian Sea, and its importance as a route for transporting energy resources from Central Asia and the Caspian Sea to Europe, make it indispensable for both Russia and other actors developing policies towards it.

Concrete actions against Russia due to the annexation of Crimea include sanctions imposed by the U.S., Canada and the EU. In the first stage, a travel ban was imposed on Russian politicians and officials involved in the annexation of Crimea. Their foreign bank accounts were also frozen. These actions, implemented since July 2014, have made it difficult for Russian companies in defence and energy and its leading state-owned banks to get loans and export products. However, this diplomatic and economic isolation has not forced Russia to step back, although it is clear that, in general, the Ukraine crisis has improved cooperation between the U.S. and the EU. The most visible platform for this cooperation is NATO.

\section{THE IMPACT OF THE UKRAINE CRISIS ON NATO-RUSSIA RELATIONS AND THE DILEMMA OF DISAGREE-RECONCILIATION}

The first official response by NATO to the developments in Crimea was made after the meeting of the North Atlantic Council held on March 2, 2014. NATO leaders expressed their concerns about the Russian Federation's use of armed force in Ukrainian territory. Emphasizing Ukraine's independence and territorial integrity, the statement demanded that Russia be faithful to its international commitments, (NAC, 2014a). On 4 March 2014, Poland called for an extraordinary meeting to discuss collective defence based on Article Four of the North Atlantic Treaty. Article Four of the Treaty, which is the previous step to collective defence, allows any ally to consult with the others if it feels its security, territorial integrity or independence are under threat (Reuters, 2014). NATO's response to the referendum held in Crimea was harsh. The day after the referendum, it was declared by NATO that the results of the referendum would not be recognized (NAC, 2014b). 
On 1-2 April 2014, NATO Foreign Ministers agreed to strengthen the collective defence of the alliance's territory and to signal solidarity with NATO's Baltic and Eastern European allies. They also decided to suspend military and civilian cooperation with Russia (NATO, 2014).

It should be highlighted that this is not the first time that the NATORussian relations have been suspended. Rather, since the end of the Cold War, the cited relations have fluctuated, with various conflicts followed by periods of cooperation. ${ }^{5}$ JONKOPINGS-NORRKOPINGJONKOPINGSNORRKOPINGDuring this time, Russia has maintained relations with NATO through institutional arrangements, such as the Partnership for Peace in 1994, the Founding Act in 1997 and the NATO-Russia Council in 2002. NATORussia relations were suspended after NATO's intervention in Kosovo in 1999 and following Russian intervention in Georgia in 2008. However, the Ukraine crisis has had a more significant impact on solidarity among NATO members and on NATO policies (Bağbaşlıoğlu, 2015: 5).

In particular, NATO has begun to increase its military presence, particularly in Poland, Romania and the Baltic States for the purpose of improving the defence capacities of member states, as decided at the Foreign Ministers Meeting in June 2014. In June 2014 NATO foreign ministers agreed on a Readiness Action Plan, and the Connected Forces Initiative, which aims to enable the member forces to communicate and work with each other.

\section{THE WALES SUMMIT: A TEST FOR NATO'S SOLIDARITY}

At the London Summit on 5-6 July 1990, NATO officially declared the end of the Cold War and took substantial decisions to transform Europe's security architecture. In an interesting coincidence, the first NATO summit after July 1990 was again hosted by the United Kingdom but this time discussions focused on whether a new cold war was starting. The most fundamental issues discussed at the Wales Summit concerned the future relations with Russia and the security of the Alliance's eastern borders given the Ukraine crisis, declining defence budgets, the withdrawal from Afghanistan, and the threat of Islamic State of Iraq and the Levant (ISIL). Besides the Wales Summit Declaration, the allies adopted several documents, namely a Joint Statement of the NATO-Ukraine Commission, a Declaration on Afghanistan and a Declaration on the Transatlantic Bond.

5 A considerable amount of literature has been published on how the relationship between NATO and Russia has developed. For more information, see (Forsberg and Herd, 2015: 43-51; Cross, 2015: 151-177). 
Crucially, the Wales Summit reaffirmed that collective defence is NATO's core mission. The true challenge that the Wales Summit had to overcome was to adequately recreate the Alliance in a way that would deter further aggressive steps, maintain credibility and demonstrate its resolution without reverting to Cold War attitudes, while incurring no more than minimal costs for nations (Lasconjarias, 2014: 5). The allies agreed to establish a Very High Readiness Joint Task Force within the NATO Response force as a spearhead unit, able to deploy at very short notice, particularly at the periphery of NATO's territory. The allies also agreed that all NATO members whose current defence expenditure is below the two percent commitment will aim to increase their defence expenditure in real terms as their gross domestic product (GDP) grows to move towards the two percent guideline within a decade (NAC, 2014c). Other appropriate deterrence measures included a permanent air, land, and maritime presence and meaningful military activity in European States, and increasing the preparedness levels of various other NATO forces.

However, putting the abovementioned measures into practice is not as easy as adding them to a summit statement. While these are noteworthy on paper, they are belated measures in practice. Although NATO summits usually take decisions easily and by consensus, their implementation tends to be delayed. The most remarkable example of this is an agreement reached by NATO allies in 2002 in which they agreed to commit a minimum of two percent of GDP to spending on defence. However only four of twenty-eight member states (the U.S., Estonia, Greece and Great Britain) have implemented this commitment so far. At the Wales Summit, NATO leaders reaffirmed this two percent defence spending commitment, replacing an indefinite timeline with one within the next decade, although it is a non-binding political commitment. It should be stated that the two percent defence spending commitment and the commitment by members to raise the investment quota to twenty percent of the defence budget is not very credible for every NATO member given the continued impact of the recent financial crisis. According to a report on European military capabilities, further reductions will inevitably occur due to a mix of demographic pressures and budgetary necessities. For example, over the next 20 years, EU countries will have to allocate one percent of their GDP just to repay debts accumulated during the financial crisis (Missiroli, 2013: 12). Another reason why these commitments are not credible is the diverging threat perceptions of NATO members. Thus, rising defence spending in Poland and the Baltic states reflects their perception of a threat.

Another example relates to the NATO Response Force, which is seen as a 
way to get Europeans to take on more responsibility for their own defence. Although this was first established at the Prague Summit in 2002, it could not be implemented completely because it depends on capabilities allocated by member states. As Stanley Sloan notes, the absence of serious U.S. participation in the force was a major factor limiting its credibility and effectiveness (Sloan, 2014). Therefore, it is important to remain sceptical about decisions taken at the Wales summit to deter Russia and reassure Eastern European countries.

As for NATO's enlargement policy in the Russian Near Abroad, it would be too optimistic to assert that NATO's expansion will continue without any problems. Although the Alliance leaders again declared at the 2014 Wales and 2016 Warsaw summits that NATO's open door policy is still valid, most allies are sceptical about accepting Ukraine and Georgia, whose accessions would additionally be seen as provocative to Russia. As Kufčák (2014: 14) has noted, the postponement of Georgian and Ukrainian membership has clearly indicated the gap between NATO's open door rhetoric and its policies. The Ukraine crisis could not remove all differences within the alliance. These diverse preferences result from rather than cause the effectiveness of the Euro-Atlantic security system.

\section{AFTER THE WALES SUMMIT: OLD HABITS, NEW CHALLENGES}

After the declarations made at the Wales Summit, NATO increased its deterrence capability and made moves directed towards the Black Sea and Baltic regions. After a Russian aircraft violating Turkish air space was shot down and the increase in Russia's military presence, NATO increased its measures over the Mediterranean Sea. After the Wales Summit, the U.S. and NATO took concrete steps to increase the security of Baltic countries. NATO founded new military headquarters in member countries in Eastern Europe and the Baltic region while tripling the number of troops for its rapid reaction force (Gaist, 2016). One of the activities symbolizing the solidarity between NATO and the Baltic countries is Baltic Air Policing, which has been carried out beginning from March 2004 when Estonia, Lithuania and Latvia joined to NATO. This activity has been further intensified after the Wales Summit. NATO also increased the number of aircraft by modernizing the Amari Air Base in Estonia following the Ukraine crisis. Until May 2014, only four aircraft had been used for air policing mission. In addition to air policing, NATO also started observation flights over Eastern Europe and the Baltic countries with AWACS aircraft. Finally, in Poland in 2014 and in the Baltic countries in 
2015, NATO carried out conspicuous military exercises involving significant numbers of personnel and equipment. ${ }^{6}$

The crisis and Russia's policies also changed the status quo in the Black Sea. After having its solidarity and deterrence capability tested, the Alliance tried to narrow down Russia's room for manoeuver by increasing its conventional power in the Baltic countries with the measures outlined above. For its part, Russia declared in its Military Doctrine, in December 2014, that NATO was its most important threat (BBC, 2014). Russia has carried out military activities similar to NATO's while reinforcing its defenses along NATO's eastern border. Using its energy and trade cards, Russia also aims to transform the different attitudes towards it among NATO's European member states into a political fracture within the Alliance.

Russia's engagement in the Syrian crisis by initiating air strikes at the request of the Syrian government in September 2015 can be considered in this context. As Ateşoğlu Güney (2016: 16) notes, Russia wishes to compensate for its post-Cold War loss of influence in the Middle East by increasing its political, economic and, most importantly, energy influence through its support for the Assad regime. On the one hand, Russia has told international society that its presence in Syria is justified as part of the fight against ISIS, and on the other hand, it has tried to prove that it has the capacity to transfer power from the Black Sea and Baltic Sea to Syria through the Caspian Sea. Since getting involved in the Syrian crisis, Russia has violated the air spaces of several Northern and Southern European NATO member countries. At this point, we can state that Russia's efforts to politically fracture the Alliance have once again tested NATO's solidarity. NATO has stated that it supports Turkey in response to Russian air space violations. NATO Foreign Ministers have accepted that the current situations in Syria and Iraq pose risks to Turkey's border security, and declared that they have decided to take additional measures to reinforce Turkey's air defenses. One of the most recent manifestations of NATO's solidarity is the mission initiated in the Aegean Sea in March 2016, where several problems had occurred between Turkey and Greece. Thus, while Russia has legitimized its military presence in Syria through its fight against ISIS, NATO has justified its presence in the Mediterranean by starting a patrol mission to slow the refugee migration and stop human trafficking. Russia is clearly uncomfortable with this situation. These developments are very significant in respect to NATO's solidarity to Turkey, which has faced

6 For more information about NATO and NATO related exercises, see (Lukasz, 2016: 11-15).

660 Hitit Üniversitesi Sosyal Bilimler Enstitüsü Dergisi - Yıl 9, Sayı 2, Aralık 2016 
different risks following Russia's intervention in Syria and after Germany and the U.S. withdrew their Patriot missile batteries from Turkey.

\section{CONCLUSION}

At Wales Summit, the Alliance's leaders approved the Readiness Action Plan to strengthen its capabilities, especially those related to NATO's collective defence and crisis management tasks. Within the framework of this plan, NATO has decided to strengthen the NATO Response Force and establish a joint force at a high level of preparedness. One of the most significant effects of the crisis for NATO's solidarity concerns increasing defence spending, which has been falling, and to come up with a decision to invest in priority needs in terms of defence and military.

The Ukraine crisis and Russia's policies have changed the status quo in the Black Sea. After the crisis, the Alliance tried to narrow Russia's room for manoeuver by increasing its conventional power in the Baltic countries with the abovementioned measures. Russia has carried out military activities similar to those of NATO by reinforcing its defenses along NATO's eastern border. Russia has also aimed to transform the different attitudes towards Russia among European NATO member states into a political fracture. The continuation of this increasing tension will have serious implications for NATO's solidarity and identity, and it may affect the ranking of priorities among NATO's fundamental tasks. The situation may also disrupt NATO's cooperative security, which is one of its three essential core tasks. Affiliate programs are the most important instruments of cooperative security. It should be taken into account that NATO's partnership programs were developed and successfully implemented when NATO-Russian relations were more harmonious. Since these activities will not be welcomed by Russia in today's international conjuncture, it can be said that prioritizing collective defense will adversely affect NATO's security approach based on cooperation (cooperative security), which aims to improve political dialogue with non-NATO countries, in the medium term. It is also clear that abandoning cooperative security, which is essential to NATO's transformation, will weaken NATO's claim to be a global security organization.

I have discussed in this article the Ukraine crisis as a problem in which NATO's deterrence function, which is vital for NATO to continue as a strong alliance, has been tested in the context of relations with the Russian Federation. The attitudes of NATO members given the Ukraine crisis may play a significant role in reshaping the future of the Alliance. This potential is of extreme 
importance, not only in respect to testing NATO's deterrence function, but also in the context of the ongoing debates on NATO's future. The solidarity and attitudes exhibited in the Ukraine crisis will be decisive as to whether NATO will continue as a strong alliance or become an ineffective coalition of volunteers.

\section{REFERENCES}

BAĞBAȘLIOĞLU, Arif. (2015), Is NATO's Presence Fading In Russian Near Abroad In Tımes of Change?”, Karadeniz Araştırmaları Dergisi, Vol. 12, No. 47, 1-16.

BBC. (2014), "Rusya'da Yeni Askeri Doktrin: En Büyük Tehdit NATO” (26 December 2014), $B B C$, (erişim adresi: http://www.bbc.com/turkce/haberler/2014/12/141226_ rusya_askeri_doktrin) (erişim tarihi: 28 Temmuz 2016).

BORGER Julian and Nicholas Watt. (24 March 2014), "G7 Countries Snub Putin and Refuse to Attend Planned G8 Summit in Russia", The Guardian, (erişim adresi: http://www.theguardian.com/world/2014/mar/24/g7-countries-snub-putinrefuse-attend-g8-summit-russia), (erişim tarihi: 28 Temmuz 2016).

BROWN, Bernard E. (2014), "Europe -and NATO- Are Back", American Foreign Policy Interests, Vol. 36, No. 3, pp 201-209.

CBSNEWS. (01 May 2014), "Russia Now an Adversary, NATO Official Says" (erişim adresi: http://www.cbsnews.com/news/russia-now-an-adversary-nato-official-says/), (erişim tarihi: 28 Temmuz 2016).

CROSS, Sharyl. (2015), "NATO-Russia Security Challenges in the Aftermath of Ukraine Conflict: Managing Black Sea Security and Beyond", Southeast European and Black Sea Studies, Vol. 15, No. 2, p. 151-177.

FORSBERG, Tuomas and Herd, Graeme. (2015), "Russia and NATO: From Windows of Opportunities to Closed Doors", Journal of Contemporary European Studies, Vol. 23, No. 1, pp. 43-51.

GAIST, Thomas. (11 February 2016), "NATO to Send Thousands of Troops to Forward Bases in the Baltics and Eastern Europe", World Socialist Web Site, (erişim adresi: https://www.wsws.org/en/articles/2016/02/11/nato-f11.html), (erişim tarihi: 28 Temmuz 2016).

GÜNEY ATEŞOĞLU, Nurşin. (2016), “Rusya Ukrayna'dan Sonra Neyin Peşinde: Bugünden Yarının Yeni İttifaklarını Düşünmek”, Ortadoğu Analiz, Vol. 8, No. 72, pp. 14-18.

HERSZENHORN, David M. (17 April 2014), "Away from a Show of Diplomacy in Geneva, Putin Puts on a Show of His Own", New York Times, (erişim adresi: http://www. nytimes.com/2014/04/18/world/europe/russia-ukraine.html?_r=0), (erişim tarihi: 28 Temmuz 2016). 
KAMP, Karl-Heinz. (2014), "From Wales to Warsaw: NATO's Future beyond the Ukraine Crisis", American Foreign Policy Interests: The Journal of the National Committee on American Foreign Policy, Vol. 36, No. 6, pp. 361-365.

KROENIG, Matthew. (2015), "Facing Reality: Getting NATO Ready for a New Cold War", Survival:Global Politics and Strategy, Vol. 57, No. 1, p. 49-70.

KUFČÁK, Jakup. (2014), "NATO after the Wales Summit: Readying the Alliance for the Future", The Web site of Association for International Affairs Policy Paper, 3/2014, (erişim adresi: http://www.amo.cz/editor/image/produkty1_soubory/ amocz_pp_2014_03.pdf), (erişim tarihi: 28 Temmuz 2016).

KyivPost. (19 March 2014), "Dmitry Rogozin: Unipolar World is Over", (erişim adresi: http://www.kyivpost.com/content/ukraine/dmitry-rogozin-unipolar-world-is-over-339928.html), (erişim tarihi: 28 Temmuz 2016).

LASCONJARIAS, Guillaume. (14-15 November 2014), NATO's Posture after the Wales Summit, IAI Working Papers.

LUKASZ, Kulesa. (2016), "Towards a New Equilibrium: Minimising the Risks of NATO and Russia's New Military Postures", European Leadership Network Policy Brief, (erişim adresi: http://www.europeanleadershipnetwork.org/medialibrary/2016/02/07/180d69f6/Towards\%20a\%20New\%20Equilibrium\%202016. pdf) (erişim tarihi: 28 Temmuz 2016).

MISSIROLI, Antonio. (2013), Enabling the Future European Military Capabilities 20132025: Challenges and Avenues, Report no: 16, European Union Institute for Security Studies, Paris.

MORELLI, Vincent L. (2016), Ukraine: Current Issues and U.S. Policy, Washington D.C.: Congressional Research Service, (erişim adresi: https://www.fas.org/sgp/crs/ row/RL33460.pdf), (erişim tarihi: 28 Temmuz 2016).

NATO. (01 April 2014), "Statement by NATO Foreign Ministers", (erişim adresi: http:// www.nato.int/cps/en/natolive/news_108501.htm), (erişim tarihi: 28 Temmuz 2016).

North Atlantic Council (NAC). (2010), “Active Engagement, Modern Defence: Strategic Concept", (erişim adresi: http://www.nato.int/cps/en/natolive/official_ texts_68580.htm), (erişim tarihi: 28 Temmuz 2016).

NAC. (2014a), "North Atlantic Council statement on the situation in Ukraine", (erişim adresi: http://www.nato.int/cps/en/natohq/official_texts_107681.htm?selectedLocale=en), (erişim tarihi: 28 Temmuz 2016).

NAC. (2014b), "Statement by the North Atlantic Council on the so-called referendum in Crimea”, (erissim adresi: http://www.nato.int/cps/en/natohq/news_108030. htm?selectedLocale=en), (erişim tarihi: 28Temmuz 2016).

NAC. (2014c), "Wales Summit Declaration”, (erişim adresi: http://www.nato.int/cps/ en/natohq/official_texts_112964.htm?selectedLocale=en), (erişim tarihi: 28 Temmuz 2016). 
Reuters. (2014), "Poland Requests more NATO consultations over Russia", (03 March 2014) (erişim adresi: http://www.reuters.com/article/2014/03/03/us-ukraine-crisis-nato-meeting-idUSBREA221VS20140303), (erişim tarihi: 28 Temmuz 2016).

SLOAN, Stanley R. (10 September 2014), "A Succesful NATO Summit? Proof Will Be in the Pudding", The Website of War on the Rocks, (erişim adresi: http://warontherocks.com/2014/09/a-successful-nato-summit-proof-will-be-in-the-pudding/\#_), (erişim tarihi: 28 Temmuz 2016).

The White House. (2014), "FACT SHEET: European Reassurance Initiative and Other U.S. Efforts in Support of NATO Allies and Partners" (03 June 2014), The website of the White House, (erişim adresi: http://www.whitehouse.gov/the-press-office/2014/06/03/fact-sheet-european-reassurance-initiative-and-other-us-efforts-support-), erişim tarihi: 28 Temmuz 2016).

UN General Assembly. (27 March 2014), "General Assembly Adopts Resolution Calling upon States Not to Recognize Changes in Status of Crimea Region", (erişim adresi: http://www.un.org/press/en/2014/ga11493.doc.htm), (erişim tarihi: 28 Temmuz 2016).

WALT Stephen M. (1987), The Origins of Alliances, New York: Cornell University Press.

WALT Stephen M. (2014), NATO Owes Putin a Big Thank-You, The Website of Foreign Policy, (erişim adresi: http://www.foreignpolicy.com/articles/2014/09/04/nato_ owes_putin_a_big_thank_you_russia_ukraine), (erişim tarihi: 28 Temmuz 2016).

WEBBER Mark, Ellen Hallams and Martin A. Smith. (2014), "Repairing NATO's Motors", International Affairs, Vol. 90, No. 4, pp 773-793. 